\title{
Dalbergia latifolia Roxb.
}

Jøker, D.

Published in:

Seed Leaflet

Publication date:

2004

\section{Document version}

Publisher's PDF, also known as Version of record

Citation for published version (APA):

Jøker, D. (2004). Dalbergia latifolia Roxb. Seed Leaflet, 90. 


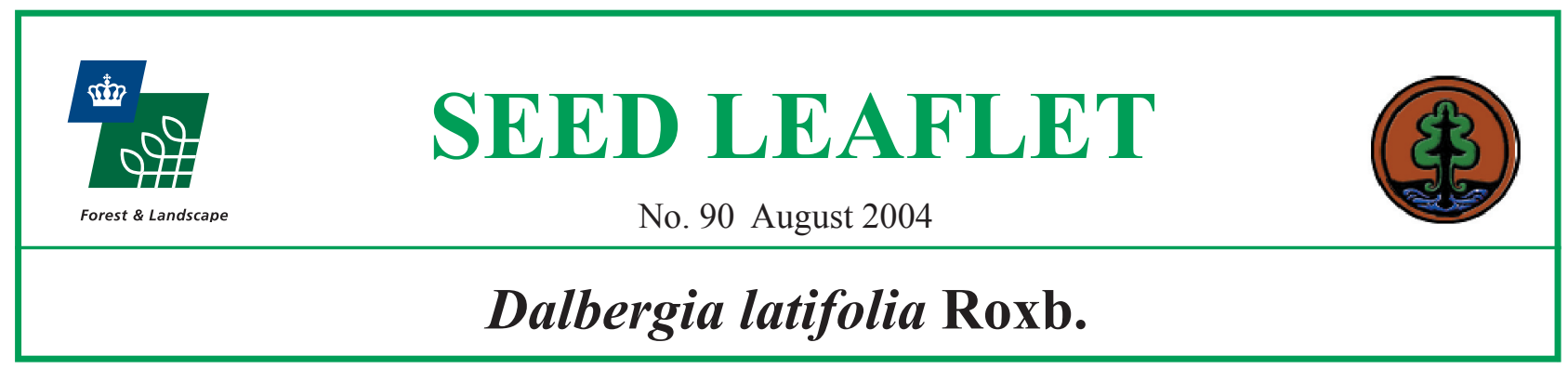

\section{Taxonomy and nomenclature}

Family: Fabaceae (Papilionoideae)

Synonyms: Amerimnon latifolium (Roxb.) Kuntze, nom. illeg., Dalbergia emarginata Roxb.

Vernacular/common names: sitsal, beete, shisham (India); satisal (Nepal); sonokeling, sonobrits (Indonesia); palisandre de l'Inde (Fr.). Indischer Rosenholzbaum (Germ.); Indian rosewood, Bombay blackwood (Eng.); rosewood (trade name).

Varieties: In Java two varieties are recognised. The native variety, called sonokeling, is straight and used in agroforestry. It seldom produces seeds and is reproduced by suckers. The naturalised variety of Indian origin, sonobrits, produces seed yearly. It is crooked, fast growing and used in land rehabilitation. The wood of sonobrits is less valuable because of crooked form and a more dull colour.

\section{Distribution and habitat}

The area of natural distribution is from the Himalayas to the southern tip of India and on the island of Java in Indonesia. It is mainly found in monsoon forests in association with species such as Tectona grandis, Albizia chinensis and Cassia fistula. It grows on deep, well-drained, moist soils, from the low plains to about $1500 \mathrm{~m}$ altitude in areas with annual rainfall of 750-5000 mm. Adult trees are tolerant of drought and ground fire, but susceptible to crown fire. It has been introduced to Sri Lanka and in Africa in Nigeria, Tanzania and Kenya.

Although not threatened, the species is heavily exploited in many places and is reported to have declined in parts of India. Protection is provided under the Indian Forest Act and export in the form of logs and sawn timber is banned.

\section{Uses}

The species is of great commercial importance because of its high-value timber. The heartwood is very hard, weighing about $850 \mathrm{~kg} / \mathrm{m}^{3}$. It is fragrant and decorative and is used to make premium-quality furniture, panelling and veneers. The species is nitrogen fixing and in Indonesia it is a popular agroforestry species. During the first three years the trees are interplanted with rice, maize, beans or cassava and later, when the canopies begin to close, they are underplanted with shade-tolerant crops like coffee, tumeric and ginger. In other systems it is grown with fruit trees like mango, annona, jackfruits and guava. The nitrogen-rich foliage is locally an important source of fodder. Tannins extracted from the bark are used for a number of medicinal purposes.

\section{Botanical description}

Single-stemmed tree up to $40 \mathrm{~m}$ tall with diameter up to $2 \mathrm{~m}$. The bole is more or less straight and is branchless for about half of the total height. Bark is grey and thin, with irregular short cracks that exfoliate in long, fibrous flakes. The root system is well developed with deep tap roots and long lateral roots. When near the soil surface, the roots can produce suckers, many of which develop into trees. Leaves are 10-30 cm long, compound, with 5-7 unequal-sized leaflets. Flowers are small and white, in 5-20 cm long inflorescences.

\section{Fruit and seed description}

Fruit: the fruit is a brown pod, up to $15 \mathrm{~cm}$ long, 1.5$2.5 \mathrm{~cm}$ wide and pointed at both ends. They contain 1-4 seeds and do not open at maturity.

Seed: the seeds are 6-7 $\mathrm{mm}$ long and 4-5 $\mathrm{mm}$ wide, smooth, shiny brown to black and flat. They are fairly hard but brittle when dry. Seed weight is very variable, with 20.000-40.000 seeds per kg.

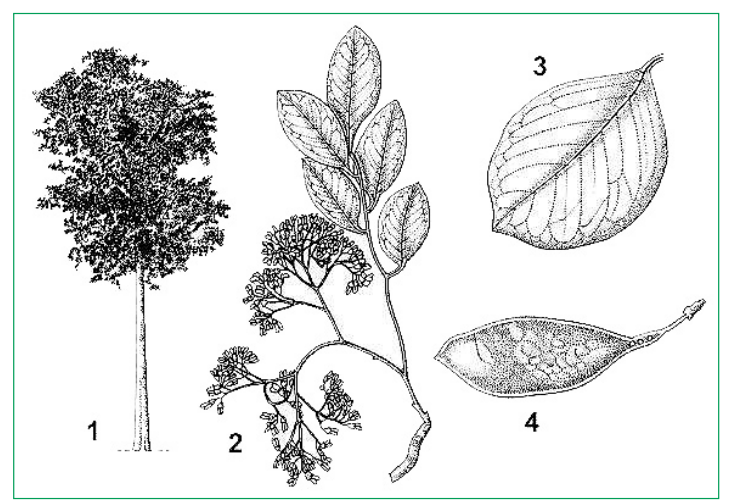

1, tree habit; 2, flowering branch; 3, leaflet; 4, pod. Copyright: PROSEA Foundation.

\section{Flowering and fruiting habit}

In areas with high rainfall the trees remain evergreen throughout the year while in drier habitats the leaves are shed by the end of January. New leaves appear in April-May and at the same time the trees begin to flower. Ripe fruits are available from October to April depending on locality. The fruits remain on the trees until the onset of the rainy season. 


\section{Harvest}

When the pods have turned dark brown they are collected from the trees by lopping the branches.

\section{Processing and handling}

After collection the pods are dried in the sun and broken into segments each containing one seed. It is not necessary to extract the seeds. The pods can be rubbed with a soft material like leather or rubber to release the seeds. The fruits should not be beaten or in any other way treated roughly as the seeds may be damaged and fail to germinate.

\section{Storage and viability}

The seeds are orthodox and should be dried to low moisture content (about 8\%) and stored in air-tight containers. Although they are orthodox, the seeds cannot be stored for long periods of time. After 9-12 months, germination will typically drop from $50-75 \%$ (fresh seed) to $30-40 \%$.

\section{Dormancy and pretreatment}

The seeds are not hardcoated and scarification is not necessary. Before sowing the seeds should be soaked in water for 12-24 hours to hasten germination.

\section{Sowing and germination}

The unit for sowing is a pod segment with one seed. Fresh seed normally germinates $50-75 \%$ in $1-2$ weeks. The seeds can be sown in containers or in well-raised seedbeds from where they are pricked out. About 3 months after sowing the seedlings are ready for planting in the field. The seedlings have a long taproot, and thorough root-pruning is necessary. Stump planting is regarded as the best method of raising D. latifolia. Stump roots and shoots should be $4.5 \mathrm{~cm}$ and 2.5-4.0 $\mathrm{cm}$ long respectively and root-collar diameter should be $0.5-1.5 \mathrm{~cm}$. To ensure a good survival, the stumps should be planted out during the rainy season. Regular weeding is essential for successful establishment and must be done until the trees are tall enough to compete. In the early stages, loosening of the soil around the plants can be done with great benefit.

\section{Selected readings}

Devi Prasad, A.G., 1994. Dalbergia latifolia - the highvalued Indian rosewood. NFT Highlights, NFTA 94-04. Winrock International.

Soerianegara, I. and R.H.M.J. Lemmens (eds.), 1993. Plant Resources of South-East Asia No. 5(1). Timber trees: major commercial timbers. Wageningen, Netherlands: $\mathrm{Pu}-$ doc Scientific Publishers.

Tewari, D.N., 1995. A Monograph on Rosewood (Dalbergia latifolia Roxb.). Milton Book Company, India.

Thomson, W., 1994. The 1994 Dalbergia latifolia (Indian rosewood/satisal) seed collection for the establishment of breeding seed orchards. HMG/Danida Tree Improvement Programme, Kathmandu, Nepal.

Troup, R.S. and H.B. Joshi, 1983. Troup's The Silviculture of Indian Trees. Vol IV. Leguminosae. Delhi, India.

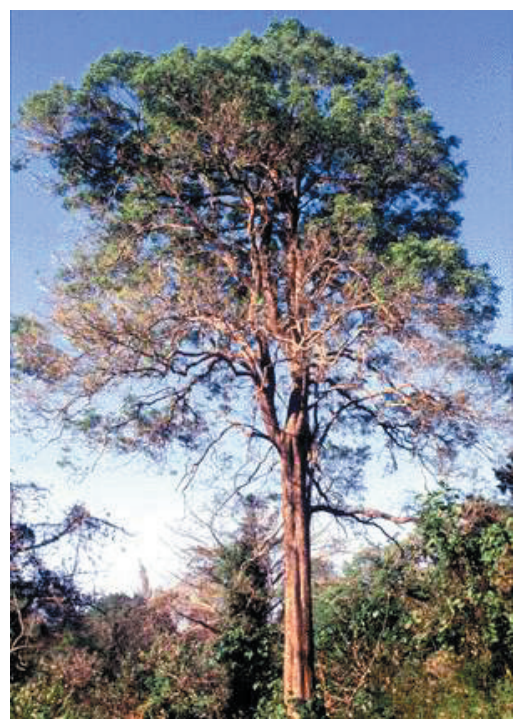

Tree habit. Copyright: Subhash Kuriakose/Kerala Forest Research Institute

THIS NOTE WAS PREPARED IN COLLABORATION WITH INDONESIA FOREST SEED PROJECT

Author: Dorthe Jøker, Forest \& Landscape Denmark
Forest \& Landscape Denmark

Hørsholm Kongevej 11

DK-2970 Hørsholm

Denmark Website:
Phone: +45-35281503

Fax: +45-35281517

Email: SL-International@kvl.dk www.SL.kvl.dk 